\title{
RESPONS PERTUMBUHAN BIBIT KARET (Hevea brasiliensis Muell.Arg) SATU PAYUNG KLON PB 260 TERHADAP PEMBERIAN DECANTER SOLID PADA MEDIA TANAH BEKAS TAMBANG BATU BARA DI POLYBAG
}

\author{
Akhir Sabri Harahap ${ }^{1}, \operatorname{Sarman}^{2}$, Rinaldi $^{2}$ \\ Jurusan Agroekoteknologi Fakultas Pertanian, Universitas Jambi \\ Jl. Raya Jambi - Ma. Bulian KM.15 Mendalo Darat, 36136 \\ Email : akhirsabri@gmail.com (*Penulis untuk korespondensi)
}

\begin{abstract}
ABSTRACK
The management of the umbrella rubber plant of a clone PB 260 in the former mine is considered to be one of the main alternative solutions to overcome the unproductive lands with the provision of a solid decanter. This research was conducted at Teaching and Research Farm Faculty of Agriculture, University of Jambi from June to September 2017 with the aim to know the best decanter dose of rubber seed growth on the former land of coal mine in polybag. This research used a Completely Randomized Design (RAL) with 6 levels of treatment (a0) Without the solid decanter, (a1) $400 \mathrm{~g} /$ polybag, (a2) $500 \mathrm{~g} / \mathrm{polybag}$, (a3) $600 \mathrm{~g} / \mathrm{polybag}$, (a4) $700 \mathrm{~g} / \mathrm{polybag}$, (a5) $800 \mathrm{~g} / \mathrm{polybag}$. Each treatment consisted of 4 replications, and each replication consisted of 4 plants and 2 plants used as samples.Based on the result of this research, it can be concluded that the provision of solid decanter to the growth of rubber seedlings (Hevea brasiliensis Muell. Arg) one umbrella with soil media used for coal mining area gives better growth to diameter, number of leaf, dry weight of crown, and root dry weight than seed rubber without a solid decanter and generally a solid decanter treatment with a dose of $500 \mathrm{~g} /$ polybag showed improved rubber seed growth better than other treatments.
\end{abstract}

Keyword: rubber seedlings the first umbrella,coal mine, solid decanter.

\section{PENDAHULUAN}

Prospek karet alam pada masa mendatang masih tetap baik, mengingat suplai pasar karet alam dunia pada masa mendatang masih terbuka dan peningkatannya terus meningkat. Peningkatan penggunaan karet alam disebabkan oleh tingginya permintaan dari negara-negara industri karet, baik untuk pasar tradisional (Amerika Serikat, Uni Eropa dan Jepang) maupun pasar baru (China, India, Rusia dan Brasil). China diperkirakan masih akan terus meningkatkan konsumsi karet alamnya hingga 4 juta ton/tahun pada tahun 2020 (Boerhendhy, 2013). 
Luas areal perkebunan karet di Indonesia pada tahun 2015 sekitar 3.656.057 ha dengan produksi 3.231.825 ton. Khusus di Provinsi Jambi tahun 2015,perkebunan karet mempunyai luas sekitar 392.259 ha dengan produksi karet 266.652ton dan produktifitas $844 \mathrm{~kg} / \mathrm{ha} /$ tahunyang meliputi $15 \%$ dari luas lahan tersebut adalah perkebunan besar swasta, sedangkan sisanya $85 \%$ merupakan perkebunan rakyat (Direktorat Jenderal Perkebunan, 2014).

Salah satu jenis karet unggul yang dianjurkan untuk daerah sumatera adalah PB 260. Klon PB 260 adalah klon penghasil lateks, pertumbuhan jagur, dan resisten terhadap Corynospora colletotricum dan Oidium, produksi lateks 1,5-2,5 ton/ha/tahun(Badan Litbang Pertanian,2010). Tanaman karet klon PB 260 merupakan penghasil lateks yang lebih unggul dari berbagai klon yang diuji, klon ini lebih tanggap terhadap kondisi lingkungan yang ada seperti relatif lebih tahan pada cekaman air yang berat (Dalimunthe,2004).

Pengelolaan tanaman karet klon PB 260 di lahan bekas tambang dinilai merupakan salah satu alternatif utama untuk mengatasi tidak produktifnya lahan-lahan tersebut sekaligus merupakan jawaban atas masalah lingkungan yang ditimbulkan kawasan bekas pertambangan. Dalam konteks agronomi, terdapat dua alasan utama dari pemilihan tanaman karet sebagai tanaman yang potensial dikelola pada lahan bekas tambang. Pertama, sejumlah penelitian dan pengalaman praktis menunjukkan bahwa tanaman karet memiliki adaptibilitas yang tinggi pada lahan-lahan yang marginal, seperti di lahan yang berbatu di kebun Palangisang SulawesiSelatan. Dalam kondisi demikian produktivitas kebun tersebut dapat mencapai $1500 \mathrm{~kg} / \mathrm{ha} / \mathrm{th}$. Tanaman karet yang mempunyai akar tunggang yang dalam secara teoritis lebih mampu mengatasi masalah kekeringan. Tanaman karet bahkan mampu memberikan produktivitas yang lebih tinggi pada lahan berpasir dengan bulan kering yang tegas dibandingkan dengan lahan yang tidak memiliki bulan-bulan kering (Suhendry et al, 1996). Kedua, tanaman karet mampu memperbaiki sifat tanah melalui perkayaan hara dengan karakter fisiologi pengguguran daunnya.

Tahun 2014Provinsi Jambimemiliki luas lahan sebesar 387.344,50 ha areal Izin Usaha Penambangan Batubara (Salam, 2016). Berdasarkan hal tersebut kemungkinan besar lahan bekas tambang batubara dapat dimanfaatkan untuk tanaman perkebunan agar lahan tersebut tetap stabil dan lebih produktif. Salah satu peluang pemanfaatannya adalah menjadikan tanah di areallahan bekas tambang batubara untuk media tanam bibit karet. Adanya lapisan tanah atas hasil dari galian penambangan batubara menjadi alternatif sebagai media bibit karet, namun dikarenakan lapisan tanah atas dilahan bekas penambangan memiliki tingkat kesuburan yang rendah serta sifat fisik, kimia dan biologi tanah yang kurang baik maka perlu adanya percobaan penggunaan media tanah dilahan bekas penambangan batubara yang diberi pembenah tanah dan diharapkan dapat memberikan pertumbuhan yang baik sebelum bibit di pindahkan ke lapangan. 
Upaya yang harus dilakukan dalam peningkatan hara tanah di lahan bekas tambang batubara adalah pemberian bahan pembenah tanah yang digunakan untuk mempercepat pemulihan kualitas tanah.Penggunaan pembenah tanah utamanya ditujukan untuk memperbaiki kualitas fisik, kimia, dan/atau biologi tanah, sehingga produktivitas tanah menjadi optimum. Pembenah tanah ada yang bersifat alami maupun buatan (sintetis). Pemberian beberapa bahan pembenah tanah organik alami mampu mempertahankan kadar bahan organik tanah seperti meningkatkan kadar $\mathrm{N}$ tanah, meningkatkan $\mathrm{pH}$ dan $\mathrm{P}$ tersedia. Kandungan tanah yang telah diberi pembenah tanah organik alami tersebut yang diharapkan dapat memberikan pengaruh baik bagi pertumbuhan dan perkembangan tanaman, serta mampu menjaga kelembapan tanah, mengurangi penguapan, penghematan pengairan, mencegah erosi permukaan, memperlancar kegiatan jasad renik tanah sehingga membantu menyuburkan tanah dan sumber humus, menghambat pertumbuhan gulma, menjaga tekstur tanah tetap remah (Nurul, 2012).

Salah satu pembenah tanah organik alami yang dimaksudkan dalam percobaan ini adalah limbah pabrik kelapa sawit. Limbah pabrik kelapa sawit terdiri atas tiga macam yaitu limbah gas, cair, dan padat. Limbah padat berupa tandan kosong kelapa sawit (TKKS) dan decanter solid(DS). Salah satu sumber bahan organik yang tersedia dalam jumlah besar adalah decanter solid yang merupakan salah satu produk akhir berupa padatan dari proses pengolahan TBS di PKS yang memakai sistem decanter (Pahan, 2008). Limbah decanter solid dari pabrik pengolahan kelapa sawit memiliki potensi yang cukup besar untuk dimanfaatkan sebagai bahan pembenah tanah organik. Decanter solidmengandung unsur hara dan zat organik yang tinggi.Mokhtarudin dan Zulkifli (1996) menyatakan bahwa unsur hara utama decanter solid kering antara lain Nitrogen (N) 1,47\%, Pospor (P) 0,17\%, Kalium (K) 0,99\%, Kalsium (Ca) 1.19\%, Magnesium (Mg) 0,24\% dan C-Organik 14,4\%.

Hasil penelitian Panjaitan (2010), pemanfaatan decanter solid dalam media tanam berpengaruh nyata terhadap tinggi bibit, diameter batang, jumlah daun, total luas daun, bobot segar dan bobot kering kelapa sawit di pre nursery. Pemanfaatan kompos solid terbaik dalam media tanam adalah kompos solid 50\% dan top soil Ultisol 50\%.

Berdasarkan uraian tersebut, maka penelitian ini bertujuan untuk mengetahui pertumbuhan bibit karet yang diberi decanter solid dengan media tanah bekas tambang baru baru di polybag. 


\section{BAHAN DAN METODE}

Penelitian ini dilaksanakan di Teaching and Research Farm Fakultas Pertanian Universitas Jambi, Desa Mendalo Darat Kecamatan Jambi Luar Kota Kabupaten Muaro Jambi. Waktu pelaksanaan penelitian selama \pm 3 bulan mulai dari Bulan Juni sampai dengan Bulan September 2017.

Alat-alat yang digunakan dalam penelitian ini adalahcangkul, parang, gembor, tali plastik, meteran, jangka sorong, label, ember, timbangan, timbangan digital, ayakan, parang, gunting, sekop, kayu, pipa paralon, oven, kamera dan alat tulis.

Bahan-bahan yang digunakan dalam penelitian ini adalah bibit karet satu payung klon PB 260,yang berasal dari Balai Pengkajian Teknologi Pertanian (BPTP) Provinsi Jambi, tanahdari lahan bekas penambangan batu bara, decanter solid, pupuk NPK, polybag ukuran $15 \times 40 \mathrm{~cm}$, dan paranet intensitas cahaya $50 \%$.

Penelitian ini menggunakan rancangan acak lengkap (RAL) dengan perlakuan dosis (A) dengan 6 taraf yaitu: $\mathrm{A}_{0}$ : Tanah bekas lahan tambang batubara sebagai kontrol (tanpa decanter solid), $\mathrm{A}_{1}: 400 \mathrm{~g} / \mathrm{polybag}$ decanter solid, $\mathrm{A}_{2}: 500 \mathrm{~g} / \mathrm{polybag}$ decanter solid, $\mathrm{A}_{3}$ : $600 \mathrm{~g} / \mathrm{polybag}$ decanter solid, $\mathrm{A}_{4}: 700 \mathrm{~g} / \mathrm{polybag}$ decanter solid, $\mathrm{A}_{5}: 800$ $\mathrm{g} /$ polybag decanter solid. Masing-masing perlakuan diulang sebanyak 4 kali, sehingga diperoleh 24 plot percobaan. Setiap plot percobaan terdiri dari 4 tanaman, sehingga jumlah secara keseluruhan terdapat 96 tanaman.

Pelaksanaan penelitian meliputi persiapan lahan penelitian, pemberian perlakuan, penanaman, dan pemeliharaan. Pengamatan yang dilakukan yaitu waktu muncul tunas payung kedua, tinggi tunas, diameter tunas, jumlah daun, persentase terbentuknya payung kedua, bobot kering tajuk, bobot kering akar. Data yang dianalisis secara statistik dengan menggunakan sidik ragam yang kemudian dilanjutkan dengan Uji BNT pada taraf $\alpha=5 \%$.

\section{HASIL DAN PEMBAHASAN}

\section{Parameter Pertumbuhan Pada Bibit Karet Payung Kedua}

Tabel 1. Rata-rata waktu muncul tunas, tinggi tunas, diameter, dan jumlah daun payung kedua pada pemberian decanter solid.

\begin{tabular}{|c|c|c|c|c|}
\hline Decanter solid $(\mathrm{g})$ & $\begin{array}{l}\text { Waktu muncul } \\
\text { tunas (HST) }\end{array}$ & $\begin{array}{l}\text { Tinggi } \\
\text { tunas }(\mathrm{cm})\end{array}$ & $\begin{array}{l}\text { Diameter } \\
\text { tunas }(\mathrm{mm})\end{array}$ & $\begin{array}{l}\text { Jumlah anak } \\
\text { daun (helai) }\end{array}$ \\
\hline Tanpa perlakuan & $47,63 \mathrm{a}$ & $19,50 \mathrm{a}$ & 5,14 & 23,88 \\
\hline 400 & $43,75 \mathrm{a}$ & $23,81 \mathrm{a}$ & $6,84 \mathrm{a}$ & $27,75 \mathrm{ab}$ \\
\hline 500 & $38,00 \mathrm{a}$ & $30,25 \mathrm{a}$ & $7,73 \mathrm{a}$ & $35,50 \mathrm{a}$ \\
\hline 600 & $44,38 \mathrm{a}$ & $24,98 \mathrm{a}$ & $6,63 \mathrm{ab}$ & $30,50 \mathrm{ab}$ \\
\hline 700 & $39,50 \mathrm{a}$ & $22,25 \mathrm{a}$ & $6,69 \mathrm{ab}$ & $31,13 \mathrm{a} \mathrm{b}$ \\
\hline 800 & $40,88 \mathrm{a}$ & $24,31 \mathrm{a}$ & $6,50 \mathrm{ab}$ & $29,63 \mathrm{a} \mathrm{b}$ \\
\hline
\end{tabular}

Keterangan : Angka-angka dalam kolom yang diikuti oleh huruf yang sama berbeda tidak nyata menurut Uji BNT dengan taraf $\alpha=5 \%$ 


\section{Persentase Terbentuknya Payung Kedua}

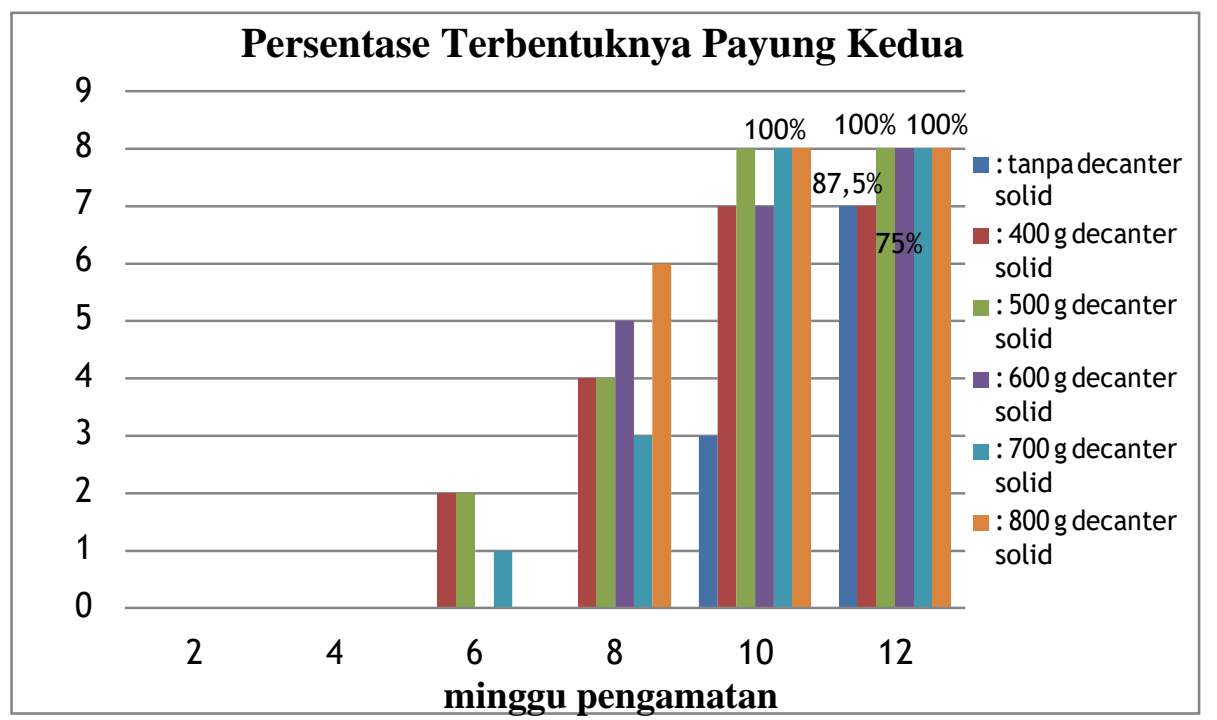

Gambar 1 : Grafik pertumbuhan payung kedua bibit karet karena pengaruh pemberian decanter solid

\section{Parameter Biomassa Bibit Karet Payung Kedua}

Tabel 2. Rata-rata bobot kering tajuk payung kedua dan bobot kering akar pada pemberian decanter solid.

\begin{tabular}{lrcrc}
\hline Decanter solid $(\mathrm{g})$ & \multicolumn{3}{c}{ Bobot kering tajuk payung dua $(\mathrm{g})$} & \multicolumn{3}{c}{ Bobot kering akar $(\mathrm{g})$} \\
\hline Tanpa perlakuan & 5,39 & $\mathrm{c}$ & 4,51 & $\mathrm{a} \mathrm{b}$ \\
400 & 9,91 & $\mathrm{a} \mathrm{b}$ & 4,15 & $\mathrm{~b}$ \\
500 & 13,31 & $\mathrm{a}$ & $6,06 \mathrm{a}$ \\
600 & 8,46 & $\mathrm{~b} \mathrm{c}$ & 4,00 & $\mathrm{~b}$ \\
700 & 10,84 & $\mathrm{a} \mathrm{b}$ & 5,21 & $\mathrm{a} \mathrm{b}$ \\
800 & 8,13 & $\mathrm{~b} \mathrm{c}$ & 3,58 & $\mathrm{~b}$ \\
\hline
\end{tabular}

Keterangan : Angka-angka dalam kolom yang diikuti oleh huruf yang sama berbeda tidak nyata menurut Uji BNT dengan taraf $\alpha=5 \%$.

Pertumbuhan tanaman dapat didefinisikan sebagai peristiwa perubahan biologis yang terjadi pada tanaman dan bersifat irreversible (tidak berubah kembali ke asal atau tidak dapat dibalik). Pertambahan ukuran tubuh tanaman secara keseluruhan merupakan hasil dari pertambahan ukuran bagian-bagian (organ-organ) tanaman akibat dari pertambahan sel (Sitompul et al, 1995). Pertumbuhan juga dapat dinyatakan sebagai 
pertambahan dalam tinggi tanaman, diameter batang, jumlah daun, berat kering akar dan berat kering tajuk.

Analisis ragam statistik pada variabel yang diamati terlihat bahwa pemberian decanter solidmemperlihatkan pengaruh yang nyata terhadap diameter tunas, jumlah daun, bobot kering tajuk payung kedua dan bobot kering akar. Sedangkan pada variabel waktu muncul tunas payung kedua dan tinggi tunas payung kedua pada pemberian decanter solid berpengaruh tidak nyata. Pemberian decanter solid 500 g/polybag memberikan hasil terbaik pada variabel waktu muncul tunas payung kedua,tinggi tunas, diameter tunas, jumlah daun, bobot kering tajuk payung kedua, dan bobot kering akar.

Analisis ragam uji BNT pada taraf $\alpha=5 \%$ menunjukkan bahwa pemberian decanter solid terhadap pertumbuhan bibit karet (Hevea brasiliensis Muell, Arg.) memberikan perbedaan tidak nyata terhadap waktu muncul payung kedua. Pemberian perlakuan $500 \mathrm{~g} /$ polybag decanter solid menunjukkan rata-rata tunas tercepat dari perlakuan lainnya yaitu 38,00 HST dan tanpa perlakuan decanter solid menunjukkan rata-rata muncul tunas terlama yaitu 47,63 HST. Munculnya tunas payung kedua merupakan tahapan awal dalam pertumbuhan tanaman karet hasil okulasi, seiring dengan perawatan dan pemeliharaan yang baik mempengaruhi proses perkembangan pada payung kedua.Hal ini diduga karena adanya pengaruh faktor genetik. Menurut Nyakpa et al., (1988) bahwa faktor-faktor yang mempengaruhi pertumbuhan bibit adalah faktor genetik (faktor dalam) dan faktor lingkungan (faktor luar).

Analisis ragam uji BNT pada taraf $\alpha=5 \%$ menunjukkan bahwa pemberian decanter solid terhadap pertumbuhan bibit karet (Hevea Brasiliensis Muell. Arg) dengan media tanah bekastambang batubara memberikan perbedaan tidak nyata terhadap tinggi tunas payung kedua. Pemberian decanter solid menunjukkan pertambahan tinggi bibit karet yang tertinggi adalah pemberian 500 g/polibag yang berbeda tidak nyata dengan perlakuan lainnya. Hal ini diduga karena adanya pengaruh curah hujan yang sedikit dan kurangnya penyiraman, mengakibatkan tanah menjadi keras.

Decanter solidmemiliki kandungan nitrogen yang berperan bagi tanaman untuk merangsang pertumbuhan tanaman secara keseluruhan, termasuk dalam mendorong dan mempercepat tumbuh atau menambah tinggi suatu tanaman serta mengaktifkan sifat kerja unsur lain.Seperti peran nitrogenmengaktifkan sifat kerja unsur fosfor. Meskipun hasil analisis decanter solid memiliki unsur fosfor yang rendah, namun perlu diketahui bahwa tanaman yang diberi nitrogen akan lebih menyerap fosfor dibandingkan tanaman tanpa diberi nitrogen, karena nitrogen mampu merangsang pertumbuhan akar dalam menyerap fosfor (Poerwidodo, 1992).Peningkatan pertumbuhan juga dapat dilihat dari peran unsur hara kaliumdalam decanter solidyang bersifat mobile, dimana unsur hara tersebut akan bergerak dibagian dewasa tanaman menuju titik tumbuh (Salisbury dan Ross, 1995).

Analisis ragam uji BNT pada taraf $\alpha=5 \%$ menunjukkan bahwa pemberian decanter solid terhadap pertumbuhan bibit karet (Hevea Brasiliensis Muell. Arg) dengan media tanah bekas tambang batubara memberikan perbedaan yang nyata terhadap pertambahan diameter bibit karet. Secara umum pemberian decanter solidke media bibit menunjukkan pertambahan diameter bibit karet. Pemberian decanter solid pada perlakuan $500 \mathrm{~g} /$ polibag menghasilkan pertambahan diameter payung dua terbesar yaitu 7,73 mm yang manapemberian perlakuan tersebut berbeda nyata dengan tanpa 
perlakuan. Berdasarkan hasil dapat dijelaskan bahwa perlakuan dengan 600 g/polybag,700 g/polybag, dan 800 g/polybag berbeda tidak nyata. Namun, berbeda nyata perlakuan 400 g/polybag dengan tanpa perlakuan. Decanter solid sebagai pembenah tanah memberikan kontribusi hara dalam memperbaiki sifat kimia, fisika dan biologi tanah yang mendukung bertambahnya pertumbuhan diameter.

Pembesaran diameter batang dipengaruhi oleh ketersediaan unsur kalium. Kalium berperan mempercepat pertumbuhan jaringan meristematik terutama pada batang tanaman, menguatkan batang sehingga tidak mudah rebah dan juga sangat penting dalam proses fotosintesis (Lakitan, 2000). Unsur K sangat berperan dalam meningkatkan diameter batang tanaman, khususnya dalam peranannya sebagai jaringan yang menghubungkan antara akar dan daun. Batang tanaman berperan dalam menopang bibitdan memperlancar proses translokasi hara dari akar ketajuk. Berdasarkan hasil analisis decanter solid memiliki kandungan hara $\mathrm{N}$ total sebesar $1,90 \%$, $\mathrm{P}$ total $0,26 \%$, dan $\mathrm{K}$ total $0,36 \%$.Unsur-unsur ini berperan dalam membantu pembentukan karbohidrat dan protein serta membantu translokasi fotosintat kebatang karet sehingga akan meningkatkan pertumbuhan batang.

Analisis ragam uji BNT pada taraf $\alpha=5 \%$ menunjukkan bahwa pemberian decanter solid terhadap pertumbuhan bibit karet (Hevea Brasiliensis Muell. Arg) dengan media tanah bekastambang batubara memberikan perbedaan yang nyata terhadap jumlah daun payung dua bibit karet.Menunjukkan bahwa pemberian decanter solid perlakuan $500 \mathrm{~g} /$ polybag berbeda nyata dengan tanpa perlakuan. Berdasarkan hasil dapat dijelaskan bahwa perlakuan dengan 400 g/polybag, 600 g/polybag, 700 g/polybag, dan $800 \mathrm{~g} /$ polybag berbeda tidak nyata. Namun, perlakuan $500 \mathrm{~g} /$ polybagmenunjukkan jumlah daun yang lebih baik dibandingkan dengan perlakuan lainnya, yakni 35,50 helai. Perlakuan decanter solidyang diberi perlakuan berbagai dosis juga memiliki jumlah daun yang lebih banyak dibandingkan dengan tanpa perlakuan.Hal ini diduga karena pemberian perlakuan decanter solid dapat memperbaiki sifat tanah serta tersedianya unsur hara yang lebih tinggi dibandingkan tanpa pemberian decanter solid.

Decanter solidmenyediakan unsur hara nitrogen dan fosfor yang cukup dalam media tanam, dimana nitrogen dan fosfordalam decanter soliddapat membantu proses pembelahan dan pembesaran sel yang menyebabkan daun muda lebih cepat mencapai bentuk sempurna. Hal ini sesuai dengan pendapat Lakitan (2001), bahwa ketersediaan unsur nitrogen dan fosforakan mempengaruhi daun dalam hal bentuk dan jumlah.Unsur hara yang paling berpengaruh terhadap pertumbuhan dan perkembangan daun adalah nitrogen. Bila tanaman kekurangan nitrogen, maka sintesis klorofil, protein dan pembentukan sel baru akan terhambat, akibatnya tanaman tidak mampu membentuk organ-organ seperti daun.Hal tersebut sesuai dengan Poerwidodo (1992) yang menyatakan jika pasok nitrogen cukup, daun tanaman akan tumbuh besar dan memperluas permukaan yang tersedia untuk fotosintesis.

Berdasarkan hasil pengamatan persentase terbentuknya payung kedua pada minggu ke-4 sampai minggu ke-12 berbeda-beda sesuai dengan jumlah tanaman yang membentuk payung dan tanaman yang tumbuh atau mentis.Pertumbuhan tanaman ini diduga karena adanya pengaruh dengan media tanah bekas tambang batubara, terbukti sampai minggu ke-4 belum ada satupun tanaman yang daunnya terbentuk sempurna. Pada minggu ke-8 persentase terbentuknya payung kedua sebesar 50\% dan sampai pada minggu ke-12 persentase terbentuknya payung kedua pada akhir pengamatan 
mengalami peningkatan yakni $95,74 \%$, hal ini sesuai dengan sifat decanter solid dalam melepas unsur hara yang tersedia secara perlahan (slowrealease).Hal ini didukung oleh pendapat Rinsema (1986) dalam Erviana (2012) yang menyatakan bahwa nitrogen yang berasal dari dekomposisi bahan organik sebagian langsung tersedia untuk diserap tanaman dan sisanya tersedia secara berangsur-angsur sebagai akibat proses penguraian secara mikroba.

Pertumbuhan tanaman di lapangan selain dipengaruhi oleh ketersediaan unsur hara yang mencukupi juga dipengaruhi oleh faktor genetik tanaman. Menurut (Marchino et al, 2010), terbentuknya payung kedua dipengaruhi oleh faktor dalam atau genetik dari tanaman dan dari cadangan makanan serta energi yang tersimpan selama pertumbuhan payung satu.Munculnya payung dua pada pembibitan karet tidak lepas dari energi yang tersimpan dalam bibit karet yang berasal dari hasil fotosintesis yang terjadi selama masa dormansi tanaman, makin banyak energi yang tersimpan maka makin cepat tanaman membentuk payung baru.Pada saat tanaman karet telah membentuk payung tanaman dengan baik maka pertambahan tinggi, diameter, dan jumlah daun akan terhenti, hal ini akan berlangsung beberapa waktu dan kembali akan tumbuh dengan cepat pada pertumbuhan payung berikutnya (Marchino et al, 2010)

Analisis ragam uji BNT pada taraf $\alpha=5 \%$ menunjukkan bahwa pemberian decanter solidterhadap pertumbuhan bibit karet (Hevea Brasiliensis Muell. Arg) dengan media tanah bekas tambang batubara memberikan perbedaan yang sangat nyata terhadap bobot kering tajuk payung kedua.Hal tersebut sejalan dengan meningkatnya jumlah daun yang menyebabkan peningkatanproses fotosintesis sehingga pertumbuhan vegetatif tanaman seperti daun,batang bertambah sehingga produksi berat kering tanaman juga mengalami peningkatan. Lakitan (2001), menyatakan bahwa berat kering yang terbentuk mencerminkan banyaknya fotosintat sebagai hasil fotosintesis, karena bahan kering sangat tergantung pada laju fotosintesis.

Analisis ragam uji BNT pada taraf $\alpha=5 \%$ menunjukkan bahwa pemberian decanter solidpada perlakuan 500 g/polybag menghasilkan bobot kering akar karetterbaik yaitu 6,06 g, yang mana pemberian perlakuan tersebut berbeda nyata dengan perlakuan $400 \mathrm{~g} /$ polybag, $600 \mathrm{~g} /$ polybag, dan $800 \mathrm{~g} /$ polybag. Namun, berbeda tidak nyata dengan tanpa perlakuan, dan $700 \mathrm{~g} /$ polybag. Apabila pemberian decanter solid ditingkatkan menjadi 600 g/polybag sampai dengan 800 g/polybag justru pertambahan bobot kering akar lebih rendah dibandingkan pemberian $500 \mathrm{~g} /$ polybag.

Bobot kering akar yang tinggi tidak luput dari peran decanter solidyang memiliki kandungan unsur hara nitrogen, fosfor dan kalium serta faktor tanaman itu sendiri. Selain itu, unsur $\mathrm{K}$ dalam decanter solidjuga memegang peranan penting, dimana Poerwidodo (1992) juga menyatakan bahwa ketersediaan K yang tinggi terbukti merangsang perkembangan perakaran, mendorong pembentukan akar cabang dan lateral pada rerumputan maupun afalfa.

Hasil dari keseluruhan data yang diperoleh bahwa bibit karet dengan pemberian perlakuan decanter solid memberikan hasil yang lebih baik dibandingkan dengan tanpa perlakuan. Hal ini diduga karena decanter solid belum menunjukkan perannya sebagai pupuk yang dapat meningkatkan pertumbuhan tanaman secara signifikan. Pemberian decanter solid dengan perlakuan dosis $500 \mathrm{~g} /$ polybag memberikan kontribusi hara nitrogen, fosfor dan kalium serta memperbaiki sifat kimia, fisik dan biologi tanah, dimana unsur hara tersebut dapat meningkatkan pertambahan bibit karet dengan nilai 
rata-rata pertambahan tinggi tanaman mencapai $30,25 \mathrm{~cm}$, diameter tanaman 7,73 $\mathrm{mm}$, jumlah daun rata-rata 35,50 helai, waktu muncul mentis 38,00 HST, persentase payung kedua yang terbentuk 45 tanaman, bobot kering tajuk 13,31 g dan bobot kering akar yang tertinggi pada perlakuan $500 \mathrm{~g} /$ polibag dengan nilai rata-rata 6,06 g. Demikian jika pemberian berlebihan seperti perlakuan dengan dosis tertinggi yaitu $800 \mathrm{~g} /$ polybag juga akan menekan pertumbuhan dan kurang efisien dalam meningkatkan pertumbuhan bibit karet.

\section{KESIMPULAN DAN SARAN}

\section{Kesimpulan}

Pemberian decanter solid500 g/polybag pada bibit karet satu payung umur 3 bulan berpengaruh baik terhadapdiameter tunas payung kedua, jumlah daun payung kedua, bobot kering tajuk payung kedua dan bobot kering akar.

Secara umum pemberian perlakuan decanter soliddengan dosis $500 \mathrm{~g} /$ polybag memperlihatkan peningkatan pertumbuhan bibit karet yanglebih baik dibandingkan pemberian perlakuan lainnya.

\section{Saran}

Berdasarkan penelitian yang telah dilaksanakan, disarankan menggunakan decanter solid untuk bibit karet berpayung satu karena dapat mempercepat pertumbuhan payung kedua bibit karet (Hevea brasiliensis Muell. Arg) pada umur 1,5 bulan.

\section{DAFTAR PUSTAKA}

Boerhendhy, I. 2013. Prospek Perbanyakan Bibit Karet Unggul dengan Teknik Okulasi Dini. Balai Penelitian Sembawa. Palembang.

Dalimunthe A. 2004. Tanggap pertumbuhan dan serapan hara bibit karet (Hevea brasiliensis Muell Agr) asal stum mata tidur karet terhadap ketersediaan air tanah. Tesis. Program Pasca Sarjana USU. USU e-repository 2008.

Direktorat Jenderal Perkebunan. 2014. Statistik Perkebunan Indonesia 2013-2015 KARET Rubber. Jakarta. Diunduh dari http://ditjenbun.pertanian.go.id tanggal 13 Oktober 2015 jam 10.57 wib.

Erviana, M Kusuma. 2012. Pengaruh Takaran Pupuk Kandang Kotoran Burung Puyuh Terhadap Pertumbuhan dan Hasil Tanaman Sawi Putih (Brassica Juncea L.)FakultasPeternakan Universitas KristenPalangka Raya . Kalimantan.

Lakitan B. 2000. Dasar Dasar Fisiologi Tumbuhan. Penerbit PT. Raja Grafindo Persada. Jakarta.

Lakitan, B. 2001, Dasar-dasar Fisiologi Tumbuhan. Rajawali Pers. Jakarta.

Marchino F, YM Zen, dan I Suliansyah. 2010. Pertumbuhan stum mata tidur beberapa klon entres tanaman karet (Hevea brasiliensis Muell.) pada batang bawah PB 260 di lapangan. Jerami Volume 3(3) : 167-180. 
Mochtaruddin AM and Z Subari. 1996. Modification of soil structure ao sand tailings:

2. Effect of silt, Sand And Clay Contents On Aggregate Development Using Organic Amandments. Pertanika Journal Of Tropical Agricultural Science. 19(2/3): $137-142$.

Nurul. P. 2012. Pemanfaatan Lahan Penimbunan Tambang Sebagai Media Tumbuh Tanaman Budidaya Dengan Aplikasi Dolomit Dan Seresah Tanaman Dengan Tanaman Uji Kailan. Penelitian Fakultas Pertanian Mulawarman. Samarinda.

Nyakpa, M.Y., A.M Lubis, M.A Pulung, A.G Amrah, A. Munawar, G.B Hong dan N. Hakim. 1988. Kesuburan Tanah. Universitas Lampung Press. Bandar Lampung.

Pahan, I.2008. Panduan Lengkap Kelapa Sawit : Manajemen Agribisnis dari Hulu hingga Hilir. Penebar Swadaya, Jakarta.

Panjaitan, Carlos. 2010. Pengaruh Pemanfaatan Kompos Solid dalam Media Tanam Dan Pemberian Pupuk NPKMg (15:15:6:4) terhadap Pertumbuhan Bibit Kelapa Sawit (Elaeis guineensis Jacq) di Pre Nursery. Fakultas Pertanian Universitas Sumatera Utara. Medan. (Tidak dipublikasikan).

Poerwidodo. 1992. Telaah Kesuburan Tanah. Angkasa Bandung. Bandung.

Salam. A. Lubis. 2016. Pelaksanaan Reklamasi Lahan Bekas Tambang Batubara.Kabid Pertambangan Umum Dinas Esdm Provinsi Jambi. Jambi.

Salisbury dan CW Ross. 1995. Fisiologi Tumbuhan. ITB. Bandung.

Sitompul, S.M dan Guritno, B. 1995. Analisis Pertumbuhan Tanaman. Gadjah Mada University Press. Yogyakarta.

Sitompul, H.A, H. Yetti dan A.E Yulia. 2015. Pemberian limbah cair pabrik kelapa sawit terhadap pertumbuhan bibit karet (Hevea brasiliensis) stum mini. Jurnal Online Mahasiswa FAPERTA Vol. 12(1): 1-11.

Suhendry, I, S. Ginting, R. Azwar, M.Z. Nasution. 1996. Potensi Pengembangan Tanaman Karet Pada Tanah Marginal Beriklim Kering. Studia Kasus Daerah Langga Payung Sumatera Utara Warta Puslit Karet.15(2): 67-77. 